\title{
Joint Development in the South China Sea: Is the Time Ripe?
}

\author{
Jianwei Li and Pingping Chen
}

The South China Sea disputes are very complicated. They involve six parties China (Taiwan), Brunei, Malaysia, the Philippines and Vietnam - and concern overlapping claims over both land features and maritime zones. Although it is recognized that peaceful resolution of these disputes is important to the region as well as the world, it is unlikely that this aim could be reached in any near future. Demand for resources, living and non-living, has pushed claimant States to take unilateral activities for resources exploration and exploitation in the disputed sea area. These unilateral activities are against the spirit of Declaration of Conduct for the Parties in the South China Sea (DOC) which was reached between China and the member States of the Association of Southeast Asian Nations (ASEAN) in 2002. They have met and will be meeting strong protests from other claimant States. With situations in the South China Sea being intensified since 2009, various means have been attempted and reconsidered to control the disputes from being escalated or even spilling out of control. This article discusses the concept of joint development arrangements (JDA) and its possible application in the South China Sea proper. ${ }^{1}$

The next section introduces the concept of JDA from an international law perspective and its evolution. Section II takes the South China Sea Region ${ }^{2}$ as a site for observation to study the policies of all the claimant countries in relation to JDA, followed by examination of the JDA cases in the region to which

1 For the purpose of this article, the South China Sea proper refers to the sea area which is bordered by China to the north, Vietnam to the west, peninsular Malaysia to the southwest, Brunei Darussalam and the two Malaysian states of Sabah and Sarawak to the south, and the Philippines to the east. See Jianwei Li and Ramses Amer, Recent Practices in Dispute Management in the South China Sea, in Clive Schofield (ed.), Maritime Energy Resources in Asia: Legal Regimes and Cooperation 81 (2012).

2 For the purpose of this article, the South China Sea Region includes (1) the sea area of the South China Sea proper and adjacent waters such as the Gulf of Thailand and the Gulf of Tonkin; and (2) land features of the Paracel Islands, the Spratly Islands, the Pratas Islands, and the Macclesfield Bank as well as four other island groups in the southwestern part of the South China Sea-the Anambas, Badas, Natuna, and Tambelan islands. See Li and Amer, supra note 1 , at 82 .

(C) JIANWEI LI AND PINGPING CHEN 2019 | DOI:10.1163/9789004379633_008

This is an open access article distributed under the terms of the prevailing CC-BY-NC License at the time of publication. 
one or more claimants are parties. Section IV analyzes the potential application of JDA in the South China Sea, exploring possible areas for JDA and obstacles in view. Concluding remarks are offered in Section v.

\section{Concept and Evolution ${ }^{3}$}

Discussion around joint development (JD) was triggered by the increasing oil and gas exploitation activities in the 1960s which happened in the marine areas where boundaries pass through or where claims overlapped. ${ }^{4}$ Onorato is a pioneer scholar who analyzed in detail the topic of JD from an academic perspective. ${ }^{5}$ In one of his articles published in 1977 , Onorato considers that "potential common petroleum deposit" should be preserved as the "unity of the deposit" and the several "States holding interests therein" are under obligation to exploit through "co-operation, good faith negotiation and agreement". 6 He recognized at that time that international law had not been developed which prescribed clear methods for apportionment of an international common petroleum deposit, ${ }^{7}$ but there existed a "legally plausible and practically implementable regime of law" which governs such an issue. ${ }^{8}$

The concept of JD first appeared in international law in the 1970s. By definition of the British Institute of International and Comparative Law, the term refers to "inter-State cooperation" over the offshore oil and gas in a designated sea area that is under dispute among related parties. ${ }^{9}$ This is a narrow definition of JD. Judge Gao prefers this definition. ${ }^{10}$ Other popular definitions of JD in the 1980s include those by Townsend-Gault, by Lagoni as well as by Fox et al. They all emphasize the rights which all States share to the resources in a given area and they should jointly exploit such-said resources. Lagoni divides JD activities into those across boundary and those lying in an area of

3 Part of this section is drawn from a previous joint research work, Li and Amer, supra note 1 , at $87-89$.

4 Binghui Sun, Legal Issues Regarding Joint Development of Marine Resources [Gongtong Kaifa Haiyang Ziyuan Falu Wenti Yanjiu], PhD Thesis, China University of Political Science and Law, (2000) at 3.

$5 \quad$ Ibid., at 4.

6 William T. Onorato, Appointment of an International Common Petroleum Deposit, 26 THE International AND Comparative LAW QUARTERLy 326 (1977).

$7 \quad$ Ibid., at 327 .

8 Ibid., at 336; Keyuan Zou, Joint Development in the South China Sea: A New Approach, 21 International Journal of Marine and Coastal LaW 89 (2006).

$9 \quad$ Ibid., Zou, supra note 8, at 90.

$10 \quad$ Sun, supra note 4 , at 6. 
overlapping claims." ${ }^{11}$ Zou further clarifies another category of JDA which is devised together with maritime boundary delimitation. ${ }^{12}$

JDA may trace its international legal basis as early as the 1958 Geneva Convention on Continental Shelf. The concept of shared resources and cooperation in developing them are also reflected in the 1982 United Nations Convention on the Law of the Sea (UNCLOS) and other international soft laws such as declarations from the United Nations (UN). Article 2 of the 1958 Convention provides that coastal States have exclusive sovereign rights for the purpose of exploring and exploiting the national resources on the sea-bed. ${ }^{13}$ Article 77 of UnCLOS re-emphasizes such rights. ${ }^{14}$ Regarding resources of shared nature among different States, the 1974 UN Charter of Economic Rights and Duties of States recognised the duties of relevant countries. Its Article 3 provides, ".... in the exploitation of natural resources shared by two or more countries, each state must co-operate on the basis of a system of information and prior consultations in order to achieve optimum use of such resources without causing damage to the legitimate interests of others". ${ }^{15}$ (emphasis added)

Here three issues are emphasized. First, States which share natural resources are strongly required to cooperate with each other. Second, cooperation in such a case is for the purpose of optimum use of the resources. Third, the rights of other States must be respected such as navigational rights. On 19 May 1978, Principle One of the Principles of Conduct in the Field of the Environment for the Guidance of States in the Conservation and Harmonious Utilisation of Natural Resources Shared by Two or More States was adopted in which States sharing natural resources are required to "co-operate in the equitable utilisation of shared natural resources".16

Predicting the difficulty in reaching boundary delimitation agreements in relation to overlapping Exclusive Economic Zones (EEZ) and continental

11 David Ong, The 1979 and 1990 Malaysia-Thailand Joint Development Agreements: A Model for International Legal Co-operation in Common Offshore Petroleum Deposits?, 14 INTERnational Journal of Marine \& Coastal LaW 209 (1999).

12 Zou, supra note 8, at 92.

13 Article 2 of the 1958 Convention on Continental Shelf, from the website of the UN, available at: http://untreaty.un.org/ilc/texts/instruments/english/conventions/8_1_1958_continental_shelf.pdf.

14 Article 77(2) of UNCLOS provides the same wording as that in Article 2 of 1958 Convention on Continental Shelf, United Nations Convention on the Law of the Sea, from the website of the UN, available at http://untreaty.un.org/ilc/texts/instruments/english/conventions/8_1_1958_continental_shelf.pdf.

15 Ong, supra note 11, at 214; UN General Assembly Resolution 3281(XXIX), 12 December 1974, (1975) 14 ILM 251.

$16 \quad$ Ibid. 
shelves between countries opposite to each other or with adjacent waters, Articles 74(3) and 83(3) provide that pending final agreement, the neighboring States:

in a spirit of understanding and cooperation, shall make every effort to enter into provisional arrangements of a practical nature and, during the transitional period, not to jeopardize or hamper the reaching of the final agreement. Such arrangements shall be without prejudice to the final delimitation. ${ }^{17}$

It is analyzed that the obligation reflected in these two articles contains two aspects. First, States should make every effort to enter into provisional arrangements of a practical nature. This imposes on parties a "duty to negotiate in good faith" and to take "a conciliatory approach to negotiations in which they would be prepared to make concessions in the pursuit of a provisional arrangement". 18 Such a duty is compulsory and States are under obligation not to take concrete actions but make every effort to reach provisional arrangements. ${ }^{19}$ It is further observed that States are under no obligation to enter into any provisional arrangement but must only "make every effort" to negotiate in good faith. ${ }^{20}$ The second aspect is about the obligation of the States, during this transitional period, not to jeopardize or hamper the reaching of a final agreement on delimitation. ${ }^{21}$ In this regard, "any activity which represents an irreparable prejudice to the final delimitation agreement" is a breach of this obligation. ${ }^{22}$

In regard to what constitute "provisional arrangements", UNCLOS does not offer any clarification or elaboration. One comment is that these measures could cover a wide range of activities including, inter alia, "moratoriums on all activities in overlapping areas, joint development or cooperation on fisheries, joint development of hydrocarbon resources, agreements on environmental

17 Arts. 74(3) and 83(3), unCLOS.

18 Tara Davenport, et al, Conference Report on the Conference on Joint Development and the South China Sea, organized by Center for International Law, National University of Singapore, on 16-17 June 2011, Singapore, at 13; Robert Beckman, Recent Development of the South China Sea Dispute and Prospects of Joint Development Regime, Paper presented at the International Workshop on Legal Framework for Joint Development in the South China Sea, hosted by National Institute for South China Sea Studies, 6-7 December 2012, Haikou, China, at 5 .

19 Sun, supra note 4 , at 6.

20 Beckman, supra note 18 , at 6.

21 Davenport et al, supra note 18, at 13.

22 Beckman, supra note 18 , at 6. 
cooperation, and agreements on allocation of criminal and civil jurisdiction"23 as long as they are not jeopardize or hamper the reaching of a final agreement on delimitation. Another comment offers a narrow explanation. Since the purpose is to "further the utilization of the area to be delimited" provisional arrangements should be related to exploration and exploitation of the resources in the area. ${ }^{24}$

The DOC, signed in 2002, is the first document between China and ASEAN countries in relation to the South China Sea issues. The Doc also emphasizes a spirit of "cooperation and understanding". Paragraph 5 provides that "pending the peaceful settlement of territorial and jurisdictional disputes, the Parties concerned undertake to intensify efforts to seek ways, in the spirit of cooperation and understanding, to build trust and confidence". ${ }^{25}$ Again Paragraph 6 encourages the Parties concerned to explore or undertake cooperative activities. ${ }^{26}$ Since the list of "cooperative activities" is not exhausted, it is believed that JDA of natural resources must be in the mind of negotiators during the process of negotiations leading to the final version of the DOC.

Meanwhile, earlier ASEAN documents encourage member States to cooperate regarding the exploitation of natural resources they share, including those in the maritime domain. For example, Article 19(1) of the 1985 ASEAN Agreement on the Conservation of Nature and Natural Resources, provides: "Contracting Parties that share natural resources shall co-operate concerning their conservation and harmonious utilization, taking into account the sovereignty, rights and interests of the Contracting Parties concerned in accordance with generally accepted principles of international law". ${ }^{27}$

Joint development is a temporary arrangement in nature, usually motivated by the possibility of the presence of natural resources and potential economic gains from the exploration and exploitation of concerned resources. In cases where the maritime boundary is delimited, the motivation for cooperation is for the best utilization of the resources. As for agreements in a disputed area, signatories to JDAs seem more motivated by the desire to reach a swift agreement for immediate exploration and exploitation. A second motivation may be the fear that the resources in question may fall on the "wrong" side of the

\footnotetext{
23 Ibid., at 9 .

24 Rainer Lagoni, Interim Measures Pending Maritime Delimitation Agreements, 78 ThE American Journal of International LaW 354 (1984).

25 Declaration of Conducts of the Parties in the South China Sea, from the website of ASE$\mathrm{AN}$, available at http://www.asean.org/asean/external-relations/china/item/declarationon-the-conduct-of-parties-in-the-south-china-sea.

26 Ibid.

27 Ong, supra note 11, at 214.
} 
delimitation line in the absence of knowledge of their exact location. ${ }^{28}$ The shared desire for economic gain leads to mitigation of the potential for conflicts such that related parties search for a provisional arrangement for cooperation in the disputed area, with the view that resolution of the sovereignty issue could be very time-consuming. The cooperative nature reflected in JDAs helps settle the concerned dispute temporarily by putting potential conflicts under control. ${ }^{29}$ Meanwhile, JDAs can been seen as an attempt to fulfill an obligation under UNCLOS. As to the South China Sea region on which this study focuses, JDAs also reflect the efforts from claimant States in implementing the Doc. This approach has been explored in the South China Sea Region where bilateral as well as multilateral maritime disputes exist.

Cooperative relations are very important for neighboring countries to initiate JDAs in maritime areas either straddling the boundaries or with overlapping claims. On the other hand, JDAs can further promote friendship between neighboring countries, and the benefits can spill over to other areas in interState relations. ${ }^{30}$ The political will reflected from government policies is vital to such country-to-country cooperation. To judge possibilities of application of JDA in the South China Sea region, it is necessary to first analyze policies of relevant claimant States.

\section{A Policies of Claimant States \\ $1 \quad$ China ${ }^{31}$}

To manage maritime disputes with its neighbors, China prefers direct bilateral consultation and negotiation. China has never opted for any form of third party involvement, including judicial settlement, good office, mediation, and conciliation. On 25 August 2006, China submitted to the United Nations a declaration under Article 298 of UNCLOS, which ruled out the compulsory dispute settlement procedures concerning disputes over maritime delimitations,

28 Clive Schofield, Unlocking the Seabed Resources of the Gulf of Thailand, 27 ContempoRARY SoUtheast Asia 288 (2007).

29 Ibid., at 298-299.

30 Anon, Feasibility and Restraints regarding Application of Joint Development in the Spratlys Area [Gongtong Kaifa Shiyong Yu Nansha Zhi Kexingxing Ji Xianzhi], available at http:// nccuir.lib.nccu.edu.tw/bitstream/140.119/37032/9/301509.pdf.

31 This part is updated and revised from a previous joint research work. Li and Amer, supra note 1 , at $92-94$. 
historic bays or titles, military activities, or those in which the Security Council of the United Nations exercises its functions. ${ }^{32}$ One earlier Chinese government white paper on maritime affairs declares:

In view of the strategy of peace and development, the Chinese Government uphold that the disputes should be resolved through friendly consultation, and that pending the final resolution, disputes could be put aside while cooperation shall be strengthened for promoting joint development. ${ }^{33}$

Such a declaration indicates China's basic policy on dispute management. First, disputes shall be resolved by peaceful means through friendly consultation based on the principle of equity and existing international law. Second, the reiterated notion of joint development reflects China's exploration in searching for alternative peaceful means in managing its maritime disputes before they are finally resolved.

Within China, the concept of joint development, together with "putting aside the dispute" (over sovereignty), was initiated by Deng Xiaoping during his 1978 visit to Japan when the dispute over the Diaoyu Islands was raised at a press conference. He was quoted as saying that the issue of the Diaoyu Islands "can be put aside. Maybe our next generation is cleverer than us and could find a real resolution to it". ${ }^{34}$ Application of this approach to the South China Sea issue was also first raised by Deng at his meeting with the Philippine vice president in June 1986. Deng was quoted as saying that the issue of the Nansha/Spratly Islands "involves more than one country". He continued by stating that from "a practical view, we opt to put aside this issue. Maybe in several years' time, the Chinese Government could propose a solution acceptable to all parties concerned". In his meeting with his Philippine counterpart Corazon Aquino on 16 April 1988, Deng reiterated, "After many years of

32 China's declaration reads that "the Government of the People's Republic of China does not accept any of the procedures provided for in Section V of Part XV of the Convention with respect to all the categories of disputes referred to in paragraph 1 (a) (b) and (c) of Article 298 of the Convention", United Nations website, available at http://www.un.org/ Depts/los/convention_agreements/convention_declarations.htm\#China\%2oUpon\%20 ratification.

33 Zhongguo Haiyang Shiye de Fazhan [The Development of China's Ocean Affairs], PeopleNet, available at http://www.people.com.cn/GB/channel2/10/200oog10/226233.html; and Zhang Liangfu, Zhongguo yu Linguo Haiyang Huajie Zhengduan Wenti [Dispute over Maritime Delimitation between China and its Neighboring Countries] 280 (2006). 
consideration, we think that to solve the issue [the Nansha/Spratly Islands], all parties concerned could explore joint development under the premise of admitting China's sovereignty over them". ${ }^{35}$ The meaning of Deng's words at these two occasions can be deduced as, for China putting aside the dispute over the Spratlys does not mean that China gives up its sovereignty claim, and joint development is the practical choice for all parties concerned to manage their sovereignty dispute. This stance is not contradictory with "without prejudice" principle in Articles 74(3) and 83(3).

From then on, top Chinese leaders have reiterated China's proposal on joint development at various occasions. In 1990, Chinese Prime Minister Li Peng, during his visit to Malaysia, expressly put forward the joint development proposal as "shelving the disputes and developing jointly" (gezhi zhengyi, gongtong kaifa $).{ }^{36}$ At the 25th ASEAN Ministerial Meeting in Manila in July 1992, after Foreign Minister Qian Qichen raised the proposal, he stated that "when conditions are ripe, we can start negotiations". In 2003, when Wu Bangguo, Chairman of the National People's Congress, visited the Philippines, he proposed to his Filipino counterpart joint development of petroleum in the South China Sea.

China's policies of managing maritime disputes with its neighboring countries by peaceful means, including the application of JDA, are consolidated by its commitments under international law or regional documents. China ratified UNCLOS in 1996 and signed the DOC with ASEAN countries in 2002. The latter signifies a further step leading to setting aside the sovereignty and maritime boundary disputes and jointly developing the resources. ${ }^{37}$

In conclusion, China emphasizes peaceful means for dispute settlement regarding the South China Sea issues and pending the final settlement, JDA and cooperation on broader economic issues are proposed as the practical solution for dispute management for building confidence among relevant disputants.

$2 \quad$ Vietnam

Oil and gas resources in the South China Sea are very important for Vietnam to achieve its goal of building Vietnam into a regional maritime power by 2020 which was adopted by the Central Committee of Vietnamese Communist Party in January $2007 \cdot{ }^{38}$ It is expected that Vietnam's oil output will peak in 2013 reaching $370,640 \mathrm{~b} / \mathrm{d}$ and gas production will rise from an estimated $8.6 \mathrm{bcm}$

35 Zhang, supra note 33, at 281-285.

36 Zou, supra note 8, at 102.

37 Beckman, supra note 18 , at 3 .

38 National Institute for South China Sea Studies, Special Report on Resources Development in the South China Sea: Policies and Practices (Forthcoming). 
in 2012 to $12.2 \mathrm{bcm}$ by $2016 .{ }^{39}$ Vietnam moved fast with rapid exploration and development of its offshore oil and gas resources to support its industrialization, but as Valencia and Van Dyke rightly put, "as long as maritime boundaries remain in dispute, foreign oil companies will be reluctant to take concessions or explore these areas". ${ }^{40}$ Finding a practical approach to developing oil and gas resources would be one best approach pending the settlement of maritime disputes.

In the 1970s, China-Vietnam boundary negotiations in the Gulf of Tonkin were triggered by the prospect for oil and gas in the Gulf. In the 1980s, Vietnam proposed that the two countries undertake a joint development program in the Gulf. After nearly 28 years of negotiation, China and Vietnam reached a maritime delimitation agreement for the Gulf of Tonkin in December 2000, in which JDA is cited as an approach for exploitation of oil and gas resources straddling the boundary. ${ }^{41}$ China and Vietnam also signed a fishery agreement at the same time. During the meeting between Chinese and Vietnamese Premiers in October 2004, both assessed highly the value of the two 2000 agreements with emphasis of the importance of cooperation. ${ }^{42}$ During President Hu Jintao's State visit to Vietnam from 15-17 November 2006, a joint communiqué was released in which JDA was raised as a means to keep stability in the South China Sea. It was promoted that both sides "shall actively discuss and negotiate on the issue of joint development in order to find appropriate models and areas". ${ }^{43}$ During the meetings between top leaders from both countries in May and October 2008 respectively, two types of cooperation on oil and gas resources are emphasized. The first is to "as soon as possible carry out joint survey in the sea area outside the mouth of the Gulf of Tonkin". The second is to reiterate active discussion on JD to find out appropriate model and area for cooperation. ${ }^{44}$ Vietnamese President Truong Tang Sang met Chinese President Xi Jinping on 19 June 2013. When Xi emphasized China's willingness

39 Vietnam Oil and Gas Report Quarter 1, available at http://www.aetin.eu/news/oil-gasvietnam-may-turn-LPG-exporter-by-2015/vietnam-oil-and-gas-report-q1-2013/.

Mark J. Valencia and Jon M. Van Dyke, Vietnam's national interests and the law of the sea, 25 OCean Development and International Law 219 (1994).

41 Details are offered in the following case study.

42 China and Vietnam issued a joint communiqué [Zhong Yue Fabiao Lianhe Gonggao], from the website of Ministry of Foreign Affairs of the People's Republic of China, available at http://www.fmprc.gov.cn/mfa_chn/ziliao_611306/1179_611310/t163636.shtml.

43 China and Vietnam issued China-Vietnam Joint Communiqué [Zhongguo he Yuenan Fabiao 'Zhong-Yue Lianhe Shengming', from the website of Ministry of Foreign Affairs of the People's Republic of China, available at http://www.fmprc.gov.cn/mfa_chn/ziliao_ 611306/1179_611310/t280705.shtml.

44 China-Vietnam Joint Communiqué, from the website of Ministry of Foreign Affairs of the People's Republic of China, available at http://www.fmprc.gov.cn/mfa_chn/ziliao_ 
"to strengthen the frequency of meetings and efforts of the working group to concurrently push ahead JD and maritime delimitation in the area outside the mouth of the Gulf of Tonkin", Sang responded by emphasizing Vietnam's wish to actively discuss delimitation as well as JD in the sea area outside the mouth of the Gulf of Tonkin. ${ }^{45}$

Vietnam ratified UNCLOS in 1994 and is bound by the obligations under UNCLOS, including making every effort to negotiate to reach some provisional arrangements, such as JDA, in relation to offshore oil and gas resources. Vietnam is a signatory to the 2002 DOC as well as to the 2011 guiding principles on implementation of the DOC, ${ }^{46}$ therefore it is politically bound by the cooperative spirit reflected in these two regional documents.

In conclusion, through the top leaders' speeches, bilateral communiqués and regional and international treaties to which Vietnam is a party, Vietnam advocates JDAs. The government also came into JD agreement with Malaysia in 1992.

3

The Philippines

The Philippines ratified UnCLOS on 8 May 1984 and is also a signatory of the Doc. As such the Philippines is bound by the obligations stated in UNCLOS and should respect the principles of the DOC including the principles of "cooperation" and "self-restraint in the conduct of activities that would complicate or escalate disputes and affect peace and stability".

The Philippines' several administrations have openly expressed the willingness to shelve the disputes for the sake of cooperation. On 11 August 1995, China and the Philippines reached an eight-point "code of conduct" regarding the issues in the South China Sea, in which both countries emphasized the importance of building confidence and trust between the two countries ${ }^{47}$ and the readiness of cooperation raised by all claimants in the South China Sea. ${ }^{48}$ At the ASEAN Summit meeting of the same year, President Ramos recommended

611306/1179_611310/t460818.shtml; China-Vietnam Joint Communiqué, available at http:// www.fmprc.gov.cn/mfa_chn/ziliao_611306/1179_611310/t519489.shtml.

45 Xi Jinping met Vietnamese President Truong Tan Sang and emphasized that China and Vietnam shall walk unswervingly along the road of friendship and cooperation, available at http://www.fmprc.gov.cn/mfa_chn/zyxw_602251/t1051627.shtml.

46 Hereinafter referred to as the "2011 Guiding Principles".

47 Articles 2 and 3 of the Joint Statement of the RP-PRC Consultations on the South China Sea and on Other Areas of Cooperation, 9-10 August 1995, in Hong Thao Nguyen, Vietnam and the Code of Conduct for the South China Sea, 32 Ocean Development And InterNATIONAL LAW 125-126 (2001).

48 Article 5 of the 1995 China-Philippines "Code of Conduct", ibid. 
that all parties concerned shelve the dispute over sovereignty to the Spratly Islands and withdraw the soldiers stationed in the features. ${ }^{49}$

Support on JDAs has been reflected in several China-Philippines bilateral communiqués. During the State visit to China by President Arroyo in 2004, a joint communiqué was issued which provides that "pending the final resolution of disputes over territory and maritime rights, both sides continuously explore means of cooperation including joint development". ${ }^{50}$ In 2005, when Chinese President Hu paid a State visit to the Philippines after the signing of the China- Philippines-Vietnam Joint Marine Seismic Undertaking Agreement (JMSUA), leaders from both countries expressed their welcome to such cooperation agreement. ${ }^{51}$ Even Aquino III whose administration takes a tougher position in their dispute with China expressed their willingness to JDAs. During the Huangyan Dao (Scarborough Shoal) Incident in May 2012, Aquino III responded to a question of JDA in the disputed area by saying that "resources exploration by means beneficial to the whole region will reduce our dependence on oil import from Middle East and NATO".52

In January 2013, the Philippines started arbitral proceedings against China requesting the arbitral tribunal to rule on the conformity of China's U-shaped line with UNCLOS and China's activities on some land features in the Spratlys. ${ }^{53}$ It was observed that in relation to dispute management in the South China Sea, the Philippines now opted for international arbitration instead of direct means including JDAs. ${ }^{54}$

49 Anon, supra note 30, at 74.

50 Joint Communiqué between the People's Republic of China and the Republic of the Philippines [Zhonghua Renmin Gongheguo Yu Feilubin Zhengfu Lianhe Gonggao], from the website of Ministry of Foreign Affairs of the People's Republic of China, available at http://www.fmprc.gov.cn/mfa_chn/ziliao_611306/1179_611310/t155753.shtml.

51 China and the Philippines issued a joint communiqué, from the website of Ministry of Foreign Affairs of the People's Republic of China, available at http://www.fmprc.gov.cn/ mfa_chn/ziliao_611306/1179_611310/t193789.shtml.

52 Jinlu Zhou, The Philippine President Raised JD in the South China Sea, Saying Impossible to compete with China, available at http://news.qq.com/a/20120518/ooo175.htm.

53 The Secretary of Foreign Affairs on the UNCLOs Arbitral Proceedings against China, available at http://www.gov.ph/2013/o1/22/statement-the-secretary-of-foreign-affairs-on-theunclos-arbitral-proceedings-against-china-january-22-2013/; Ministry of Foreign Affairs of the Republic of the Philippines, Notification and Statement of Claim on the West Philippine Sea, available at http://www.dfa.gov.ph/index.php/newsroom/dfa-releases.

54 Malaysian PM echoes Beijing's call for joint development in South China Sea, available at http://www.scmp.com/news/asia/article/1253564/malaysian-pm-echoes-beijings-calljoint-development-south-china-sea. 
4

Malaysia

Malaysia signed UNCLOS on 10 December 1982 and ratified it in 1996. As to the disputes in the scs, Malaysia favors peaceful resolution through negotiation. In 2005, China's Premier Wen Jiabao and Malaysia's Prime Minister Abdullah Badawi signed a joint communiqué, in which it is stated that both China and Malaysia welcome concrete cooperation in the disputed waters in the scs under guidelines of shelving the dispute for joint development. ${ }^{55}$ In 2011, the Malaysia Deputy Minister of Foreign Affairs A. Kohilan Pillay stated, "Joint development of natural resources may be an interim measure that could be taken by countries with overlapping claims over the area". According to him, Malaysia favors negotiation with the concerned States to settle the maritime dispute. The third party, however, like the ICJ, should be the final option. ${ }^{56}$ Malaysia's Prime Minister Najib also called for the claimants in the South China Sea to jointly develop resources to avoid conflict and prevent "extra-regional States". ${ }^{57}$

Malaysia holds an open attitude toward JDAs and on many occasions its leaders expressed their willingness for JDAs in disputed waters. Malaysia has carried out several JDAs with its neighbor countries, such as the 1979/1990 Malaysia-Thailand JDA, the 1992 Vietnam-Malaysia JDA. Recently, when finalizing the delimitation of maritime boundaries between the two countries, Malaysia proposed joint oil exploration with Brunei. ${ }^{58}$

\section{$5 \quad$ Brunei}

In 1984, after independence, Brunei signed UNCLOS and ratified it in 1996. As to the dispute in the South China Sea, Brunei insists that the relevant disputes should be resolved through peaceful dialogue and consultations by the concerned sovereign States.

In 2005, during the visit to Brunei, President $\mathrm{Hu}$ proposed joint development in the South China Sea with Brunei. On 5 April 2013, President Xi and the Sultan of Brunei Haji Hassanal Bolkiah signed a joint statement which states that both countries and the concerned companies will continue to deepen cooperation in

55 The joint communiqué of People's Republic of China and Malaysia, from the website of Ministry of Foreign Affairs of the People's Republic of China, available at http://www.fmprc. gov.cn/chn/pds/ziliao/zt/ywzt/2005year/wjbzlfw/t226666.htm.

56 Parliament: Malaysia Favours Peaceful Resolution To Maritime Boundary Dispute, 6 April 2011, available at http://maritime.bernama.com/news.php?id=576829\&lang=en.

57 Malaysian PM echoes Beijing's call for joint development in South China Sea, available at http://www.scmp.com/news/asia/article/1253564/malaysian-pm-echoes-beijings-calljoint-development-south-china-sea.

$5^{8}$ Malaysia proposesjoint oil exploration, The Brunei Times, 7 August 2009, available at http:// www.bt.com.bn/home_news/2009/08/07/malaysia_proposes_joint_oil_exploration. 
energy sector. As toJDAs, "The Leaders agreed to support relevant enterprises of the two countries to carry out joint exploration and exploitation of maritime oil and gas resources following the principle of mutual respect, equality and mutual benefit. Such cooperation shall not be interpreted as to prejudice the position of the respective countries in relation to maritime rights and interests". ${ }^{59}$ This is the first time that JD is mentioned in the joint statement or communiqué between the two countries. Brunei also expressed its openness to JDAs.

\section{B}

Joint Development Cases in the Region

Joint Development Arrangements for Resources

Straddling Boundaries

There are two cases under this category, the 2000 China-Vietnam maritime delimitation and fishery cooperation agreements for the Gulf of Tonkin and the 2009 Brunei-Malaysia maritime delimitation agreement.

\section{a}

\section{China-Vietnam Agreements ${ }^{60}$}

The maritime delimitation agreement of 25 December 2000 on the Gulf of Tonkin $^{61}$ is the first maritime boundary agreement between China and Vietnam. It is also China's first maritime boundary agreement. The maritime boundary agreement uses a single line for both the continental shelf and Exclusive Economic Zone (EEZ). On the same day, the two countries signed an agreement on fishery cooperation in the Gulf of Tonkin. ${ }^{62}$ On 29 April 2004, the Supplementary Protocol to the Agreement on Fishery Cooperation in the Gulf of Tonkin and regulations on preservation and management of the living resources in the Common Fishery Zone in the Gulf of Tonkin were signed. ${ }^{63}$ On 30 June 2004, both boundary and fishery agreements entered into force following the completion of the ratification process. ${ }^{64}$

59 Article 9 and 10 of the joint statement, the full text is available at http://www.fmprc.gov. cn/eng/wjdt/2649/t102940o.shtml.

6o This part is revised from a joint research in which one author is involved. Li and Amer, supra note 1 , at 84 and $95^{-9} 8$.

61 Hereinafter, the 2000 Delimitation Agreement.

62 Hereinafter, the Fishery Agreement, Hong Tao Nguyen, Maritime Delimitation and Fishery Cooperation in the Tonkin Gulf, 36 Ocean Development and International LaW 35-41 (2005); Keyuan Zou, The Sino-Vietnamese Agreement on Maritime Boundary Delimitation in the Gulf of Tonkin, 36 Ocean Development and International LaW 127-148 (2005).

63 Protocol on China-Vietnam agreement on fishery cooperation in Beibu Bay signed, People's Daily Online, available at http://english.people.com.cn/200404/30/eng20040430_142001. html, accessed on 5 May 2013.

64 Two China-Vietnam Beibu Gulf agreements take effect, People's Daily Online, available at http://english.peopledaily.com.cn/200407/01/eng20040701_148157.html. 
The above agreement shows the spirit of support for JDA from both governments. Article 7 of the 2000 China-Vietnam Agreement reads:

In case that any single geophysical structure of oil and gas or other mineral deposits should straddle the demarcation line as provided in Article 2 of this Agreement, the Parties shall, through friendly consultation, reach an agreement on the development of the structure or deposit in a most effective way as well as on equal sharing of the profits resulting from the development. ${ }^{65}$

An agreement on joint oil exploration in the Gulf of Tonkin was signed on 16 November 2006. 66

Meanwhile, the Fishery Agreement is an example of a two-step solution for settling fishing disputes and delimiting the EEz and related arrangements aiming for better conservation and utilization of the living resources shared by both countries. Coordination and cooperation reflected in the fishery arrangements contribute to reasonable utilization and sustainable development of living resources as stated in the Delimitation Agreement. ${ }^{67}$ The regime of the EEZ with regard to fisheries is to be applied after four years for the Transitory Arrangements (TA) and after fifteen years for the Common Fishery Zone $(\mathrm{CFZ}){ }^{68}$ Several mechanisms were included to supervise the implementation of the two agreements. The Joint Fishery Committee (JFC) is in charge of the implementation of the Fishery Agreement. The expert-level group organized a two-year joint research program in the CFZ from 2006 to 2007 which includes two phases with seventeen aerial surveys.

65 Appendix: Agreement on the Delimitation of the Territorial Seas, Exclusive Economic Zones and Continental Shelves in the Beibu Gulf between the People's Republic of China and the Socialist Republic of Vietnam, in Zou, supra note 62, at $22-24$, Appendix B: Agreement between the Socialist Republic of Viet Nam and the People's Republic of China on the Delimitation of the Territorial Sea, Exclusive Economic Zone and Continental Shelf between the Two Countries in the Tonkin Gulf, in Nguyen Hong Thao, Maritime Delimitation and Fishery Cooperation in the Tonkin Gulf, 36 Ocean Development and INTERNATIONAL LAW 41-44 (2005).

66 Gov't gives nod to Tokin Gulf oil deal with China, from the website of Viet Nam Ministry of Foreign Affairs, available at http://www.mofa.gov.vn/en/nro40807104143/nro40807105001/ nso70105093635/newsitem_print_preview.

67 Article 8 of the Delimitation Agreement provides that "the contracting parties agree to carry on negotiations on related issues regarding the reasonable utilization and sustainable development of living resources in the Beibu Gulf (the Gulf of Tonkin) as well as in the EEZ of both countries in the Gulf", reproduced in Zou, supra note 62, at 24 .

For more detail, see Zou, supra note 62 , at $30-32$. 
The expert-level talks on the delimitation of the area outside the mouth of the Gulf of Tonkin were initiated in January 2006 and the fifth meeting was held in January 2009. ${ }^{69}$ Such expert-level talks were renewed in 2012 and the latest one, dubbed as the 3 rd round, was held in May $2013 .{ }^{70}$ During the negotiation process, JDA has been emphasized together with delimitation.

All these post-2002 arrangements and on-going negotiations are beneficial to effective implementation of relevant agreements. By the Delimitation Agreement, both countries are obliged to jointly develop oil and gas resources straddling the boundary. Discussions on JDA have been undergoing since the initiation of the negotiation on the area outside the mouth of the Gulf of Tonkin. These, together with the JDA arrangement on fishery in the Gulf of Tonkin, contribute to confidence-building between the two countries, which will help China and Vietnam resolve disputes in other parts of the South China Sea.

In March 2009, through exchange of letters Brunei and Malaysia seem to have resolved their maritime boundaries. Both countries reached an agreement on establishing a "Commercial Arrangement Area" to incorporate both countries' oil blocks for sharing revenue from the exploitation of oil and gas. ${ }^{71}$ The JDA in the 2009 Brunei-Malaysia Agreement did not involve sovereignty disputes over features. It was observed that Malaysia agreed to give up its claims (and hence, its sovereign rights) over blocks of hydrocarbon resources (known as Blocks $\mathrm{L}$ and $\mathrm{M}$ ) off Borneo in exchange of participation by Malaysian oil company (Petronas) in the development of these blocks. This is an exceptional case in State practice on joint development in Asia. ${ }^{72}$ By this agreement, both countries agreed to establish a joint commercial arrangement area whereby Petronas will participate in the development of Blocks $\mathrm{L}$ and $\mathrm{M}$, although the terms of the agreement are reportedly still being negotiated. ${ }^{73}$

$69 \quad$ Ramses Amer, The Sino-Vietnamese Approach to Managing Border Disputes - Lessons, at 261.

70 Vietnam and China initiate the 3 rd round of talks for the working group for maritime delimitation for sea area outside the mouth of Beibu Bei, available at http://www.qdnd.vn/webcn/ zh-cn/120/365/380/245152.html.

71 Li and Amer, supra note 1, at 89; Joint Press Statement by Leaders on the Occasion of the Working Visit of YАВ Dato' Seri Abdullah Haji Ahmad Badawi, Prime Minister of Malaysia, to Brunei Darussalam on 15-16 March 2009, Embassy of the People's Republic of China in Negara Brunei Darussalam, available at http:// bn.china-embassy.org/eng/wlxw/t542877 .htm.

72 Davenport et al, supra note 18 , at 20-21.

$73 \quad$ Ibid., at 25 . 

Sea Areas

Under this category, two cases have been studied in detail, the 1979/1990 Malaysia-Thailand Joint Development Agreement and the 1992 MalaysiaVietnam Agreement.

\section{Malaysia-Thailand Joint Development in the Gulf of Thailand}

The overlapping area claimed by Malaysia and Thailand lies in the southwestern part of the Gulf of Thailand. (See Figure 7.1) It is located about $72 \mathrm{~km}$ offshore and covers $7,238 \mathrm{~km}^{2}$. The area corresponds with the northwestern end of the Malaysia Basin, which is estimated to have 14 trillion cubic feet of natural gas reserves. ${ }^{74}$

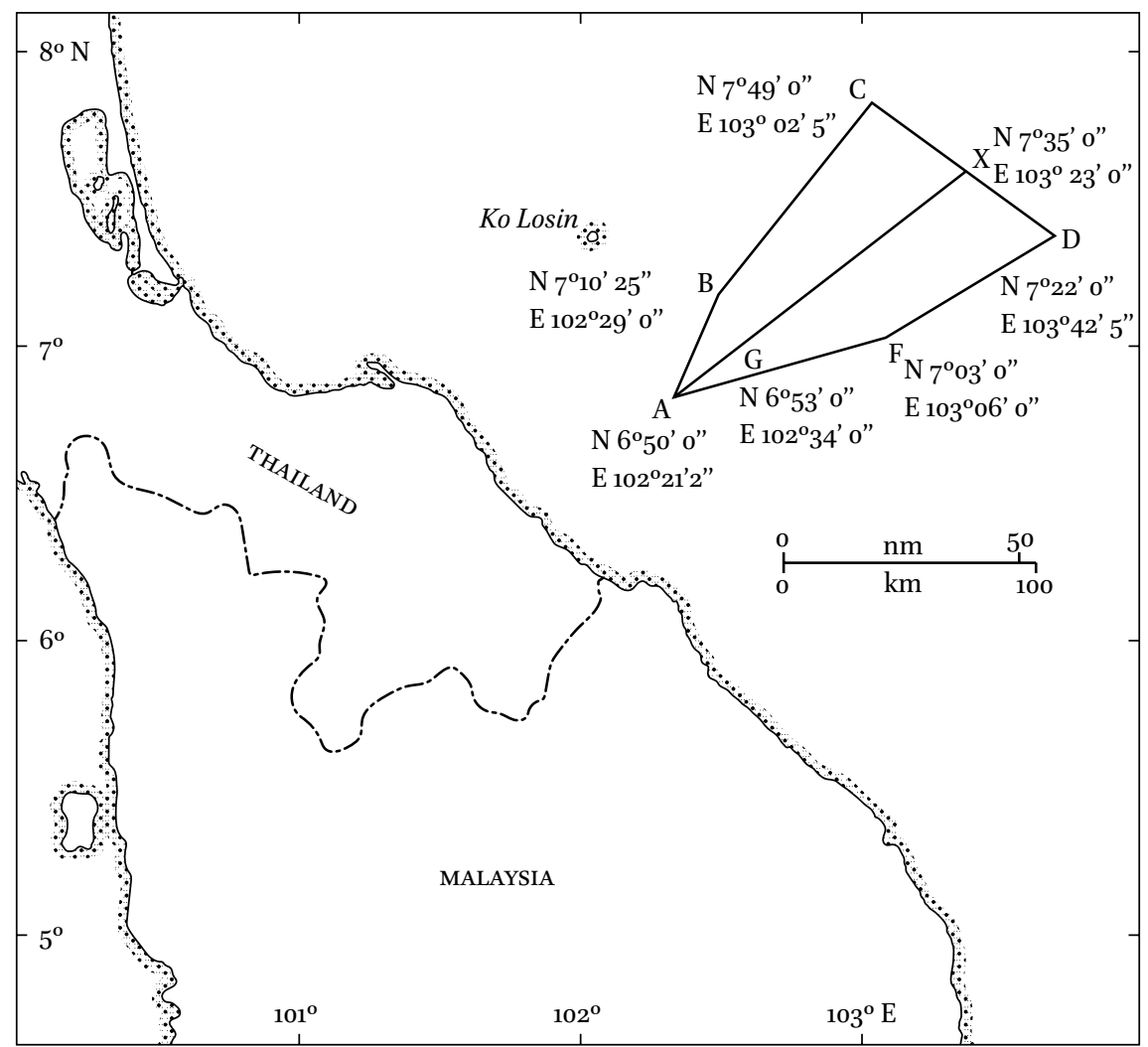

FIGURE 7.1 The area under the 1979 Malaysia-Thailand Joint Development Agreement. Source: David Ong, The 1979 and 1990 Malaysia-Thailand Joint Development Agreements: A Model for International Legal Co-operation in Common Offshore Petroleum Deposits? InTERnATIONAL JOURNAL OF MARINE \& COASTAL LAW, 14, 207 (1999), at 224. 
In 1972, Malaysia and Thailand successfully delimitated their territorial sea boundary and partial continental shelf boundary in the southwestern part of the Gulf of Thailand up to a point 29 nautical miles offshore. However, the two countries failed to delimit further continental shelf boundary due to disagreement over the effect of Ko Losin in the delimitation..$^{75}$ On 21 February 1979, Malaysia and Thailand signed a Memorandum of Understanding (MOU) on a joint development area. The Mou established a Joint Authority which has all rights and responsibilities on behalf of the two countries for exploration and exploitation of the non-living resource of the seabed and subsoil in the overlapping area. ${ }^{76}$ However, in the following 11 years, the Mou was not implemented. As Ong mentioned, the MOU is "anything other than an expression of intent between the two State parties". ${ }^{77}$ On 30 May 1990, both countries signed the Agreement between the Government of Malaysia and the Government of the Kingdom of Thailand on the constitution and other Matters Relating to the Establishment of the Malaysia-Thailand Joint Authority. ${ }^{78}$ The MOU, comprising eight articles, provides the basic principles for joint development. The Agreement follows the basic elements of joint development provided in the MOU and establishes detailed rules and regulations on implementation. ${ }^{79} \mathrm{On}$ 24 April 1994, both countries and the relevant companies signed a contract for joint development.

Even though the 1990 Agreement builds on the legal framework of the 1979 MOU, two major aspects is worth some attention. First, it established in detail the powers and functions of the Joint Authority, and second, it adopted a production sharing contract system. ${ }^{80}$ The Joint Authority consists of two chairmen, one from each country, and an equal number of members from each country. The 1979 MOU incorporated the Joint Authority, while the 1990 Agreement established its constitution. The production sharing contract system was one of the different points from the negotiation process between the two countries in 1979. According to Article 8 of the 1990 Agreement, " $50 \%$ of gross

75 Ko Losia is a islet, which is 1.5 meters high over the sea level, occupied by Thailand. Ko Losia has no economic life. Malaysia believed that the islet should not have effect on the delimitation, while Thailand insisted it is a valid basepoint. See Ong, supra note 11, at 223. Also see Nguyen Hong Thao, Joint Development in the Gulf of Thailand, IBRU BouNDARY And Security Bulletin 79-88, 81 (1990).

76 Ong, supra note 11 , at 227 .

77 Ibid.

78 Hereinafter, the "1990 Agreement".

79 Schofield, supra note 28 , at 293.

8o Masahiro Miyoshi, The Joint development of offshore oil and gas in relation to maritime boundary delimitation", 2 MARITIME BRIEFING 14 (1999). 
production to be applied by the contractor for the recovery of costs; the remainder of gross production to be profit and divided equally between the Joint Authority and the contractor; all cost of operations to be borne by the contactor, any dispute arising out of the contract to be referred to arbitration unless settled amicably".

Both the 1979 MOU and the 1990 Agreement provide that the JDA has an interim nature. Article 3(1) of the MOU states that the duration of relevant arrangements is $5^{0}$ years ${ }^{81}$ unless the delimitation agreement is reached before its expiry of the said date. ${ }^{82}$ Joint development is only a temporary solution before final resolution of delimitation of their maritime boundary.

For the purpose of jurisdiction in the joint development area, the two sides draw a criminal jurisdiction line running from north to south. However, this line does not indicate the continental shelf boundary nor prejudice the sovereign rights of either country in the area. ${ }^{83}$

The fact that it has taken over ten years for the Joint Authority to be constituted shows that JDA in the disputed area is not an easy step. Even so the success of the Thailand-Malaysia JDA provides evidence for the possibility of JDA in the disputed waters between two neighboring countries.

\section{b Joint Development Agreement between Malaysia and Vietnam}

According to the claims of South Vietnam in 1971 and Malaysia in 1979, there is an overlap of 2,80o km$~_{2}$ in the Gulf of Thailand. The overlapping area is a long sliver of sea-bed just south to south-east of the designated Malaysia-Thailand Joint Development Area. ${ }^{84}$ On 5 June 1992, Malaysia and Vietnam signed a Memorandum of Understanding (MOU) for the exploration and exploitation of petroleum in the "defined area" of the Gulf of Thailand. ${ }^{85}$ (See Figure 7.2)

81 Article 3(1) reads, "There shall be established a Joint Authority to be known as "MalaysiaThailand Joint Authority" (thereafter referred to as "the Joint Authority") for the purpose of the exploration and exploitation of the non-living natural resources of the sea-bed and subsoil in the overlapping area for a period of fifty years commencing from the date this Memorandum comes into force". 1979 Memorandum of Understanding Between Malaysia and the Kingdom of Thailand on the Establishment of the Joint Authority for the Exploitation of the Resources of the Sea Bed in a Defined Area of the Continental Shelf of the Two Countries in the Gulf of Thailand, available at http://cil.nus.edu.sg/rp/il/ pdf/1979\%2oMOU\%2obetween\%2oMalaysia\%2oand\%2oThailand-pdf.pdf.

$82 \quad$ Ibid., Article 6.

83 Article 5 of the mou, also see Miyoshi, supra note 80, at 14.

84 Ong, supra note 11, at 1999, at 242.

85 Ted L McDorman, Malaysia-Vietnam, Report No.1-19, in J.I. Charney AND L.M. AleXANDER (EDS.), VOLUME III 2335-2344 (1998). The full text of the MOU is available at ibid., 2341-2344. For more information on the background of the MOU, see Thao, supra note 75 , at $79-88$. 
The 1992 MOU provides a framework under which the two countries nominated their national petroleum companies, Petrovietnam and Petronas respectively, to hold talks directly on a commercial agreement for the purpose of joint exploring and exploiting the petroleum resources on basis of equality of rights and obligations. ${ }^{86}$ On 29 July 1997, oil was extracted successfully in the JD area, which contributed to enhancing economic development as well as their bilateral relation. ${ }^{87}$

Ong observed that there are main general principles in this JDA:

(1) such co-operation between the two parties for the exploration and exploitation of petroleum resources in the overlapping claim area has been agreed pending final delimitation of the area and is without prejudice to the position and claims of either country;

(2) in keeping with the provisional nature of the agreement, the duration of the Malaysia-Vietnam Memorandum of Understanding is for 40 years subject to any extensions and reviews that both parties may agree at a relevant juncture;

(3) all costs and benefits derived from the exploration and exploitation of the Defined Area shall be borne and shared equally by both Parties;

(4) in respect of the development and management of the petroleum resources in the Defined Area, Petronas for Malaysia and Petrovietnam for Vietnam will undertake exploration and exploitation on behalf of the two Governments; these two national oil companies will enter into a commercial arrangement between themselves for the exploration and exploitation of petroleum in the Defined Area, subject to the approval of the respective governments. ${ }^{88}$

Comparing the 1979/1990 Thailand-Malaysia JDA and the 1992 MalaysiaVietnam JDA, the defined disputed areas in both agreements are located in the Gulf of Thailand. The former agreement took ten years for the constitution of a joint authority in charge of the operation in the joint zone; in the latter agreement, Malaysia and Vietnam assigned their State-owned oil companies, Petronas and PetroVietnam respectively, to undertake petroleum exploration and exploitation in 1993, and in July 1997 oil was extracted from the Bunga Kekwa field. ${ }^{89}$

\footnotetext{
86 Ong, supra note 11, at 240.

87 Manh Dong, Maritime Delimitation between Vietnam and Her Neighboring Countries, presentation on the UN-Nippon Foundation Alumni Meeting, Tokyo, Japan, 13-16 April 2009, available at http://www.un.org/depts/los/nippon/unnff_programme_home/alumni/tokyo_alumni_presents_files/alum_tokyo_dong.pdf.

88 Ong, supra note 11 , at 242.

$89 \quad$ Li and Amer, supra note 1, at 85; Schofield, supra note 28, at 290; Zou, supra note 8, at 94; and Nguyen, supra note 75 , at $83-84$.
} 


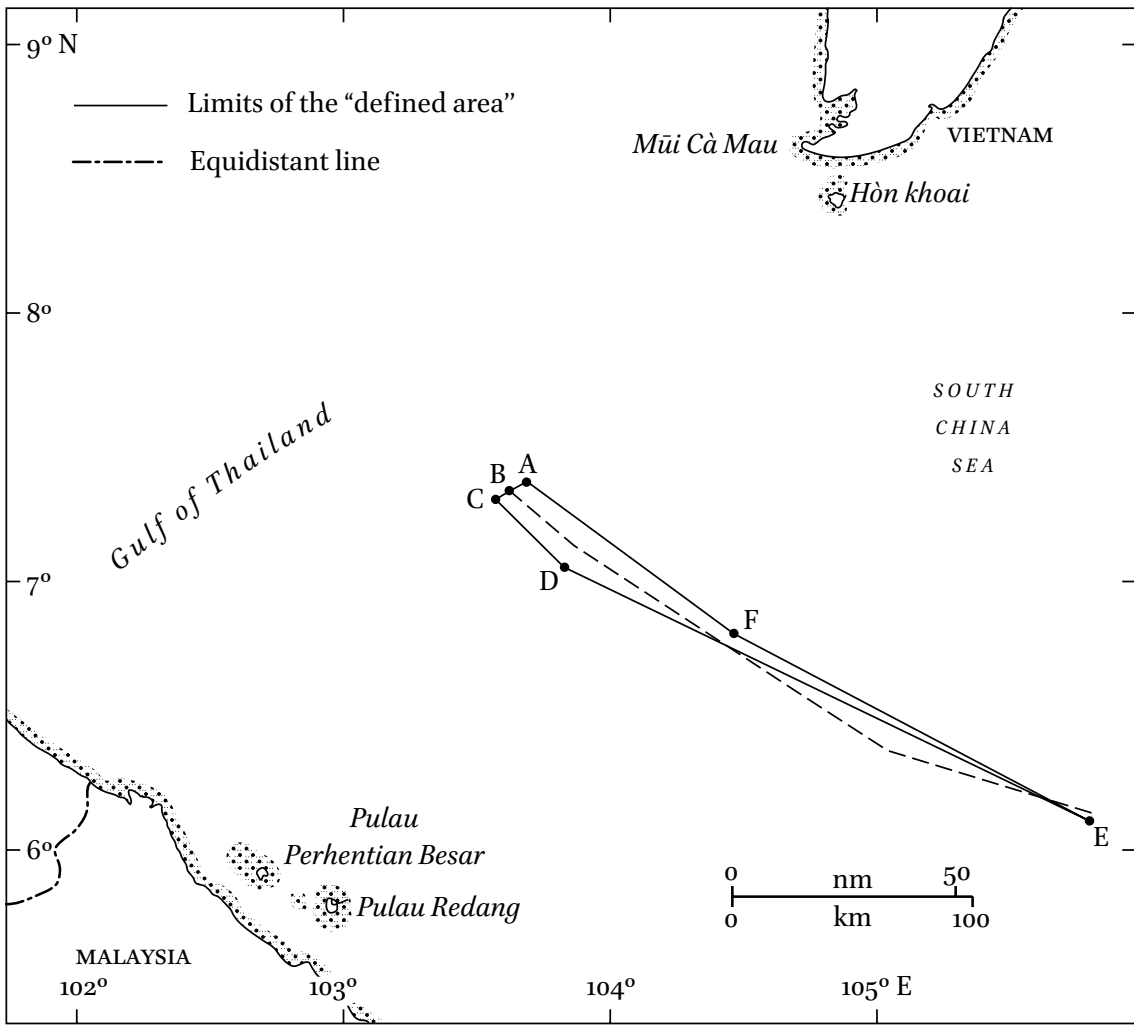

FIGURE 7.2 Illustration of the area under the 1992 Malaysia-Vietnam MoU.

Source: David Ong, The 1979 and 1990 Malaysia-Thailand Joint Development

Agreements: A Model for International Legal Co-operation in Common Offshore Pe-

troleum Deposits? 14 International Journal of Marine \& Coastal Law 207, 241 (1999)

The Malaysia-Vietnam model is viewed as more flexible than the MalaysiaThailand model because the former is unifunctional and sharply focused on facilitating petroleum exploration and exploitation at the earliest opportunity with minimal governmental participation or interference. ${ }^{90}$ More notable progress during the 199os included the initiation of trilateral talks among Vietnam, Malaysia, and Thailand regarding an area of the Gulf of Thailand where claims of the three countries overlapped. These talks were made possible by the signing of the maritime boundary agreement between Vietnam and Thailand in 1997. Although the parties agreed in principle on JD in the overlapping area, the modalities for such a trilateral scheme have yet to be agreed on. ${ }^{91}$

9o Nguyen, supra note 75, at 83; and Schofield, supra note 28, at 299.

91 Ramses Amer, Conflict Management within the Association of Southeast Asian Nations (ASEAN): Assessing the Adoption of the 'Rules of Procedure of the High Council of the Treaty of Amity and Cooperation in Southeast Asia, in Kamarulzaman AsKandar (ed.), 


\section{$3 \quad$ Joint Development Attempts ${ }^{92}$}

Under this category there are three cases, namely, the 1982 Cambodia-Vietnam historic water arrangement, the 1999 Malaysia-Thailand-Vietnam agreement and the ${ }_{2005}$ China-Philippines-Vietnam joint seismic exploration agreement.

1982 Cambodia-Vietnam Historic Water Arrangement

On 7 July 1982, Vietnam and the then People's Republic of Kampuchea (PRK) signed an agreement on "historic waters" located between the coast of Kien Giang Province, Phu Quoc Island and the Tho Chu islands on the Vietnamese side and the coast of Kampot Province and the Poulo Wai islands on the Cambodian side. The agreement stipulated that the two countries would hold, "at a suitable time", negotiations to determine the maritime frontier in the "historic waters". Pending such a settlement the two sides would continue to regard the Brévié Line drawn in 1939 as the diving line for the islands within the "historic waters" and the exploitation of the zone would be decided by "common agreement". ${ }^{3}$ On 20 July 1983, the two countries signed a Treaty on the settlement of border problems and an Agreement on border regulations. ${ }^{94}$ On 27 December 1985 the Treaty on the Delimitation of the Vietnam-Kampuchea Frontier was signed by the two countries. ${ }^{95}$ On 10 October 2005, the two countries signed a Supplementary Treaty to the 1985 Treaty. ${ }^{96}$

Management and Resolution of Inter-State Conflicts in Southeast Asia 117-118 (2003); and Nguyen, supra note 75 , at 86.

92 This part is taken from a joint research report with Ramses Amer. Jianwei Li and Ramses Amer, Recent Practices in Dispute Management in the South China Sea, in Clive Schofield (ed.), Maritime Energy Resources in Asia: Legal Regimes and CooperaTION 83 (2012).

93 For the full text of the Agreement of 7 July 1982, see British Broadcasting Corporation, Summary of World Broadcasts, Part Three, Far East, 7074 A3/7-8, 10 July 1982. The text of the Agreement has also been reproduced in English as "Appendix 2" in Kriangsak Kittichaisaree, The Law of the Sea and Maritime Boundary Delimitation in South-East Asia 180-181 (1987); and in Ted L. McDorman, Cambodia-Vietnam in Jonathan I. CHARNEY AND LEWis M. Alexander (eds.), International Maritime Boundaries, Volume ii 2364-2365 (1998). Interestingly enough, the "full text" of the Agreement transmitted by the official Cambodian news agency (SPK) on 8 July omitted the sentence: "Patrolling and surveillance in these historical waters will be jointly conducted by the two sides", which was included in Article 3 of the version published by Vietnam News Agency and reproduced in Kittichaisaree's study $(B B C / F E / 7074$ A3/8, 7076/A3/7, 13 July 1982); and Kittichaisaree, op. cit., at 180-181.

$94 B B C / F E / 7393$ A3/1 (23 July 1983). See also Quang Nghia, Vietnam-Kampuchea Border Issue Settled, 4 Vietnam Courier 8-9(1986).

95 For reports from Vietnam and the PRK announcing the signing of the Treaty and for details, see BBC/FE/8143 A3/1-3, 30 December 1985. See also, Quang, supra note 94, at 8-9.

$96 \quad P M$ Khai holds talks with Cambodian counterpart, from the website of the Ministry of Foreign Affairs of Vietnam, available at http://www.mofa.gov.vn/en/nro40807104143/ nro40807105001/nso5101140825. 
In this case, some political actors within Cambodia have opposed the agreements signed with Vietnam in the 1980s, including the 1982 Agreement on "historical waters" ${ }^{97}$ The effect of the 1982 Cambodia-Vietnam Historic Waters Agreement was that Cambodia effectively gave up its claim over Phu Quoc Island although it arguably simply endorsed a situation that had been prevalent for some time. ${ }^{98}$

b

1999 Malaysia-Thailand-Vietnam Agreement

In 1999, Malaysia, Thailand and Vietnam agreed in principle to undertake joint development in the tripartite overlapping area where Vietnam's $200 \mathrm{EEZ}$ and continental shelf overlap with the Thailand -Malaysian JDA of $1979 .{ }^{99}$ The tripartite arrangement is based on two bilateral JDAs concluded between Malaysia and Thailand in 1979, and Malaysia and Vietnam in 1992 respectively. ${ }^{100}$ The tripartite talks were made possible only by the signing of the maritime boundary agreement between Vietnam and Thailand in 1997. Although the parties agreed in principle on joint development in the overlapping area, the modalities for such a trilateral scheme have yet to be agreed on. ${ }^{101}$ When the tripartite accord becomes effective, it will be the first multilateral agreement on joint development in the region. ${ }^{102}$

c

${ }_{2005}$ China-Philippine-Vietnam Joint Seismic Undertaking Agreement The tripartite agreement started from a bilateral agreement which was signed between the Chinese oil company (CNOOC) and the Philippine National Oil Company on 11 November 2003. By this agreement, a joint committee will be set up to help select exploring areas in the South China Sea. As a follow-up, the two State oil companies signed an agreement on joint seismic work in the Sino-Philippine disputed area in the South China Sea. Applauded by the two governments as being important for maintaining peace and stability in the South China Sea, this agreement met with some opposition in the Philippines, because, put by the Philippine side, "the joint exploration will be conducted in the North-West Palawan offshore area, 'not even close enough to the Spratlys"'.103

\footnotetext{
97 Kittichaisaree, supra note 93; and Ted L. McDorman, Cambodia-Vietnam, in Jonat HAN I. Charney and Lewis M. Alexander (eds.), International Maritime BoundARIES, Volume III, 2364-2365 (1998).

98 Davenport et al, supra note 18, at 20.

99 Ana Placida D. Espina, Recent Development in the South China Sea and Prospects for Joint Development, RCAPS Working PAPER Series “Dojo”, RPD-12001, at 13.

$100 \quad$ Ibid., at 13-14.

101 Amer, supra note 91, at 117-118. Li and Amer, supra note 1, at 88-89.

102 Nguyen Hong Thao, Vietnam and Joint Development in the Gulf of Thailand, 8 Asian YEARBOOK OF INTERNATIONAL LAW 138-139 (2003).

103 Zou, supra note 8, at 103.
} 
On 14 March 2005, further developments occurred when the national oil companies of China, the Philippines, and Vietnam signed the Tripartite Agreement for Joint Marine Seismic Undertaking in the Agreement Area in the South China Sea. It was arranged that all activities in the agreement area must be discussed among the concerned parties and the seismic survey and research be carried out in a 143,000 $\mathrm{km}^{2}$ area in the South China Sea, including parts of the disputed Spratly Islands, for a period of three years. The signing of the agreement "would not undermine the basic position held by the Government of each party on the South China Sea issue". The agreement showed the determination of the involved parties to abide by the DOC and the parties expressed their "resolve to transform the South China Sea into an area of peace, stability, cooperation and development". 104

Although JMSUA was within the framework of marine scientific research and did not include any arrangements relating to exploitation of resources in the area, it is obvious that such activities aim for future exploitation therein.

In conclusion, since all disputant countries have ratified UNCLOS and they are signatories to the 2002 DOC and the 2011 Guiding Principles, they were bound legally or politically to make efforts to cooperate in the disputed waters pending the final resolution of the maritime disputes. By government statements and/or bilateral government-to-government documents between the claimant countries, all the countries expressed their willingness to come into cooperative arrangements including JDA for resources exploitation in the South China Sea. There are two successful JDA cases in the region, the 1979/1990 Malaysia-Thailand JDA and the 1992 Malaysia-Vietnam JDA. Tripartite agreements have been attempted, with one being halted and one still under discussion. The friendly inter-State relations are important for the success of any JDA, meanwhile domestic attitudes and political will within individual claimant countries could never be ignored.

Implications for the South China Sea

The South China Sea is believed to be rich in marine resources, including oil and gas. According to an estimation from the U.s. Energy Information Administration (EIA), there are approximately 11 billion barrels (bbl) of oil reserves and 190 trillion cubic feet (Tcf) of natural gas reserves in the South China Sea. ${ }^{105}$ These numbers include both proved and probable reserves. Besides

104 Revised from a joint work, Li and Amer, supra note 1, at 91.

105 EIA, South China Sea U.S. Energy Information Administration, available at http://www.eia. gov/countries/analysisbriefs/South_China_Sea/south_china_sea.pdf. 
that, the South China Sea may have hydrocarbons in underexplored areas. The U.s. Geological Survey (USGS) estimates that the South China Sea may contain between 5 and 22 billion barrels of oil and between 70 and 290 trillion cubic feet of gas in undiscovered resources. ${ }^{106}$ In the South China Sea, the sea area outside the Mouth of Gulf of Tonkin, Reed Bank (Liyue Tan in Chinese) and Vanguard Basin (Wan'an Basin) may be potential ideal areas for JDAs. (See Figure $7 \cdot 3$ )

A

Area Outside the Mouth of Gulf of Tonkin (Wankou Wai)

As suggested above, after reaching the agreement of the maritime boundaries delimitation and fishery cooperation in the Gulf of Tonkin in 200o, China and Vietnam began to negotiate the delimitation of the area outside the mouth of Gulf of Tonkin. In February 2012, Vietnam and China's Deputy Foreign Ministers held talks in Beijing. They agreed to establish working groups at the department level to negotiate on the mouth of the Gulf of Tonkin. They also agreed to set up working groups to cooperate in "less sensitive sea domains". Up till mid-2013 three rounds of talks at the department level were held to negotiate possible JDA in areas outside the mouth of the Gulf of Tonkin.107

Both countries have shown strong political will in pushing ahead with JDA in this area when negotiations on maritime delimitation are undergoing. ${ }^{108} \mathrm{How}-$ ever, one comment goes that the existence of different attitudes towards the Paracels will continue to haunt their negotiation and cooperation process. In such a case, common support for defining an area for JDA must be a welcome sign. ${ }^{109}$

\section{B Reed Bank (Liyue Tan)}

Reed Bank, claimed by both China and the Philippines, is reported to be rich in hydrocarbon resources, 3.9 million cubic feet of gas, 35 million barrels of oil and 21 billion barrels of methane hydrate. ${ }^{110}$ Recently, the Philippines carried

\footnotetext{
106 Ibid.

107 Ramses Amer and Jianwei Li, How to Manage China-Vietnam Territorial Disputes, CHInA \& US Focus, 18 April 2013, available at http://www.chinausfocus.com/print/?id=27029.

108 See the above-mentioned bilateral joint communiques in 2008 as well as talks between top leaders.

109 Anon, Gloomy prospect is observed on China-Vietnam negotiation on the delimitation of the area outside the mouth of the Gulf of Tonkin [Zhongyue Beibuwan Wankouwai Haiyu Huajie Tanpan Bei zhi Qianjing Andan] available at http://mil.huanqiu.com/Observation/ 2012-07/2884875.html.

110 Chen Bingxian, An Analysis of the South China Sea Policy of Philippines in Recent Years [Qiantan Jinnianlai Feilubin de Nanhai Zhengce], 22(5) Journal of Wuzhou University 34 (2012); Wang Lianhe, On the New Trends and Prospects of the South China Sea Disputes [Nanhai Wenti Xinqushi Ji Qianjing Chutan], 4 Southeast Asian Studies 38 (2012).
} 


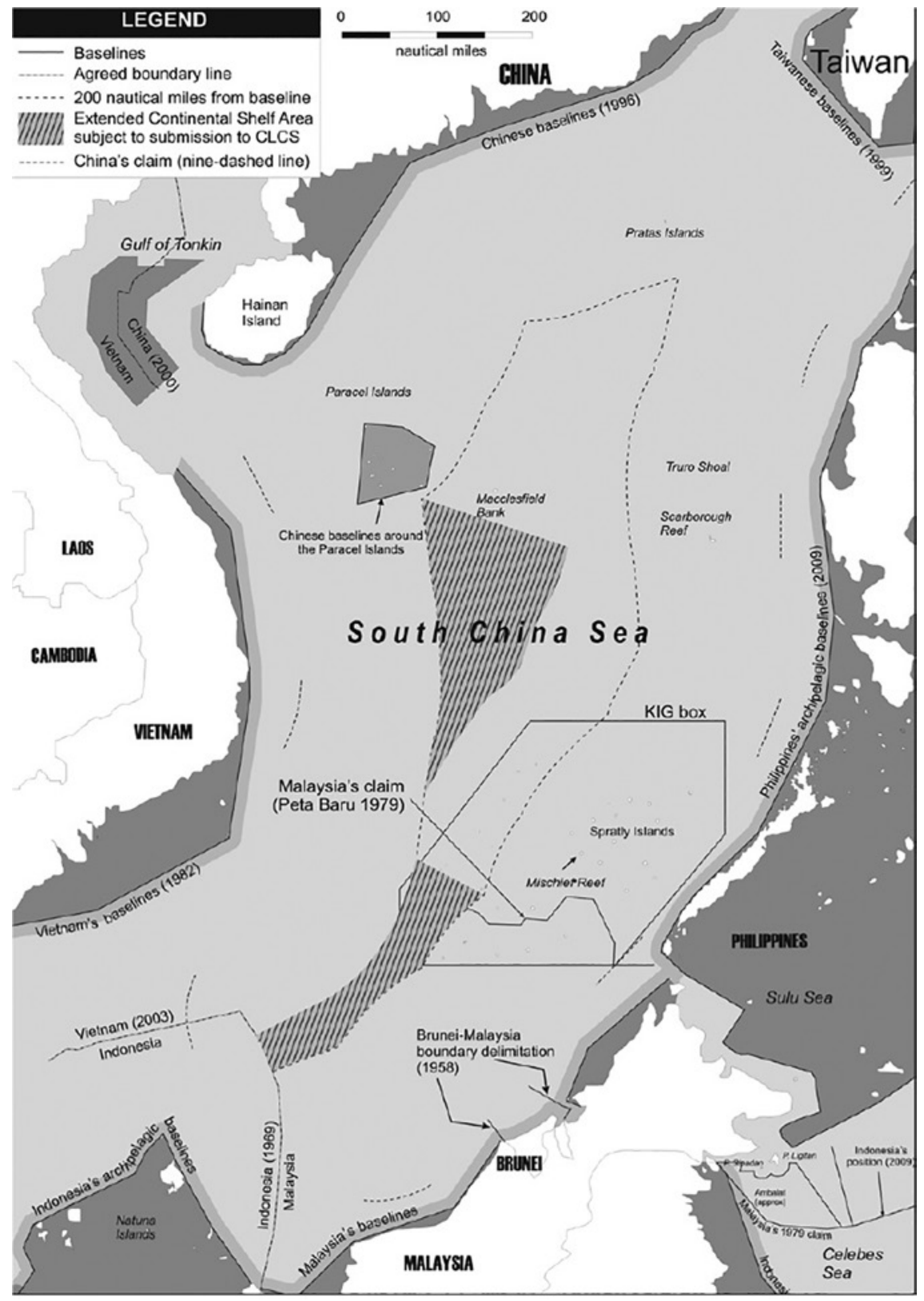

FIGURE 7.3 Illustration of areas of overlapping claims in the South China Sea proper. SOURCE: MARITIME ENERGY RESOURCES IN ASIA: ENERGY AND GEOPOLITICS, NATIONAL BUREAU OF ASIA RESEARCH (NBR) SPECIAL REPORT \#35, NOVEMBER 2011, P.VIII 
out unilateral exploration activities, which have been met with strong protests from China.

In August 2009, the Philippine government gave approval to a UK company, Forum Energy, and its partner to carry out oil and gas exploration in the area around Reed Bank. Early 2011, Forum Energy was endowed with two years' contract for oil and gas exploration in Block $\mathrm{SC}_{72}$ which is located in the disputed area. On 2 March, two fighters from the Philippine Air Force were dispatched to assist the exploration of the UK company and standoff occurred between the fighters and China's maritime patrol vessels. ${ }^{111}$ On 30 June, the Philippine Ministry of Energy issued a commercial bidding of 15 oil blocks, part of which are perceived by China as located in the disputed area. ${ }^{112}$

In 2012, during the period of the "Huangyan Island Incident", it was reported that a Philippine mining company was negotiating with CNOOC to pursue JDA for oil and gas off the Liyue Bank. In response to the report, Chinese spokesman stated, "We support more exchanges and cooperation between Chinese and the Philippine companies. On the oil and gas development in waters off the Liyue Bank, China's attitude is clear. The Liyue Bank is part of China's Nansha Islands. It will harm China's rights and interests if the Philippines engage in unilateral development in this area. China is firmly opposed to that. At the same time, China is ready to discuss joint development with the Philippines. But the key is that they should show sincerity".13

Since mid-2011, the Philippines and Vietnam have taken measures in which it is indicated that they are moving ahead to explore and exploit the hydrocarbon resources in areas which they believe to be not in disputed area while China believes to be under their jurisdiction. ${ }^{114}$ Tensions increased due to these perceived unilateral exploration activities. It was suggested that the claimant States, at least China, the Philippines and Vietnam, take immediate steps

111 Ian Lewis, China rattles its sabre over disputed reserves, Petroleum Economist, May 2011.

112 Ju Hailong, South China Sea Policy of the Philippines: Interest Driven Policy Choice [Feilubin Nanhai Zhengce: Liyi Qudong De Zhengce Xuanze], 3 Journal of Contemporary Asia-Pacific Studies 86 (2012).

113 China Minister of Foreign Affairs, 2102, Foreign Ministry Spokesperson Hong Lei's Regular Press Conference on 9 May 2012, available at http://medan.chineseconsulate.org/eng/ fyrth/t930925.htm.

114 Ramses Amer, and Jianwei Li, Recent Developments in the South China Sea - Assessing the China-Vietnam and China-Philippines Relationships, Paper prepared for the International Conference on Recent Development of the South China Sea Dispute and Prospects of Joint Development Regime, Organised by the National Institute for South China Sea Studies, Haikou, China, 6-7 December 2012. 
to clarify their claims and define the areas in dispute (and not in dispute), ${ }^{115}$ which would be beneficial to initiation of JDA.

Zou in 2006 listed three reasons for the claimant countries to take JDA in the South China Sea. First, political will is strong because all the claimant countries in the South China Sea region need a good environment for their social and economic development, and JDAs can stabilize the South China Sea region. Second, JDAs can lead to rational use of the South China Sea resources when competition of different kind of uses and among surrounding countries are increasing. Third, through JDAs confidence can be enhanced among claimant countries, which is conducive to expanding regional cooperation. ${ }^{116}$ Furthermore, the increasing demand for offshore energy resources coupled with the difficulty to do so due to territorial disputes make JDAs an attractive choice for the claimant countries. ${ }^{117}$

The advantages of JDAs which Zou listed above exist in the South China Sea. The two pushing factors, namely, demand for energy and difficulty for unilateral exploration which the CIL conference report pointed out are increasing. Now maybe the time is coming for the claimant countries to pool together their determination and to negotiate through persistence and compromise to put JDAs from paper to reality. Beckman's suggestion of finding the disputed waters which may be generated from what all agree as disputed land features might be a feasible way to start with.

\section{Conclusion}

It may be still true that a customary rule enjoining JDAs is ultimately not proven and the concept of JDA is still evolving. JDAs may expand to cover any cooperative arrangements for activities at sea where a boundary passing through or delimitation negotiations are undergoing and where rational utilization of the marine resources therein requires ignoring those artificial boundaries. JDAs are attempts to fulfill an obligation under UNCLOS. As to the South China Sea region, JDAs also reflect the efforts from claimant States in implementing the Doc.

All claimant States involved in the South China Sea disputes have experienced JDAs one way or another, successful ones or ones in principle. There are two successful JDA cases in the region, the 1979/1990 Malaysia-Thailand

\footnotetext{
115 Beckman, supra note 18 , at 12.

116 Zou, supra note 8, at 98.

117 Davenport et al, supra note 18 , at 34 .
} 
JDA and the 1992 Malaysia-Vietnam JDA. Tripartite agreements have been attempted, with one joint seismic exploration being halted and the other among Malaysia, Thailand and Vietnam under discussion. The friendly inter-State relations are important for the success of any JDA, meanwhile domestic attitudes and political will within individual claimant countries will also affect such practices. Various JDAs in the broader South China Sea Region have provided useful models for international legal co-operation on the exploitation of common hydrocarbon deposits, as well as options for the most disputed South China Sea proper.

It seems that time has come for some sort of JDA to happen in one way or another. China, as the largest State in size and economic power, needs to play a major role in the search for conflict management measures, including JDA, before the final resolution of the South China Sea disputes. Once a small step forward is made, such as a JDA in the area where there are only two claimants - outside the mouth of the Gulf of Tonkin between China and Vietnam or around Reed Bank between China and the Philippines, the region will be moving towards long-term peace and stability. 